\title{
Irrigation Trends in Kansas, 1991-2011
}

\author{
By Joan F. Kenny and Kyle E. Juracek
}

\section{Abstract}

This fact sheet examines trends in total reported irrigation water use and acres irrigated as well as irrigation water use by crop type and system type in Kansas for the years 1991 through 2011. During the 21-year period, total reported irrigation water diversions varied substantially from year to year as affected primarily by climatic fluctuations. Total reported acres irrigated remained comparatively constant during this time, although acreages of irrigated corn increased and center pivots with drop nozzles became the dominant system type used for irrigation.

\section{Introduction}

Irrigated agriculture is a fundamental component of the Kansas economy. Typically, about 3 million acres in the State are used for irrigated agriculture. Principal irrigated crops include alfalfa, corn, sorghum, soybeans, and wheat. In Kansas, irrigation is a beneficial use requiring a water right, and about 96 percent of water used for irrigation is groundwater (Kansas Department of Agriculture and Kansas Geological Survey, 2013). Most of the irrigation points of diversion are located within the extent of the High Plains aquifer that underlies much of western and part of south-central Kansas (fig. 1). The saturated thickness of the aquifer in many parts of Kansas has declined steadily since the 1940s (McGuire, 2009) in response to groundwater pumping for irrigated agriculture. Annual water-level measurements from a network of wells in western and central Kansas indicate an average decline of 14 feet between 1996 and 2012. The average regional water-level declines for this period were 32.5 feet in southwest Kansas, more than 10 feet in west-central and northwest Kansas, and 1 foot or more in south-central Kansas (Kansas Geological Survey, 2013).

Administration of water rights and regulation of water use in Kansas are the responsibility of the Kansas Department of Agriculture, Division of Water Resources (DWR). Irrigators are required by law to report the quantity of surface water and groundwater diverted (hereafter referred to as "water use") and the number of acres irrigated to the DWR annually. Additional information collected on annual irrigation water-use reports includes crop type and irrigation system type. This fact sheet examines trends in total reported irrigation water use and acres irrigated as well as irrigation water use by crop type and system type in Kansas for the years 1991 through 2011. Average irrigation application rates by crop type and system type also are presented.

Information on irrigation water use, irrigated acres, crop type, and system type was obtained from the Water Information Management and Analysis System (WIMAS) (Kansas Department of Agriculture and Kansas Geological Survey, 2013).

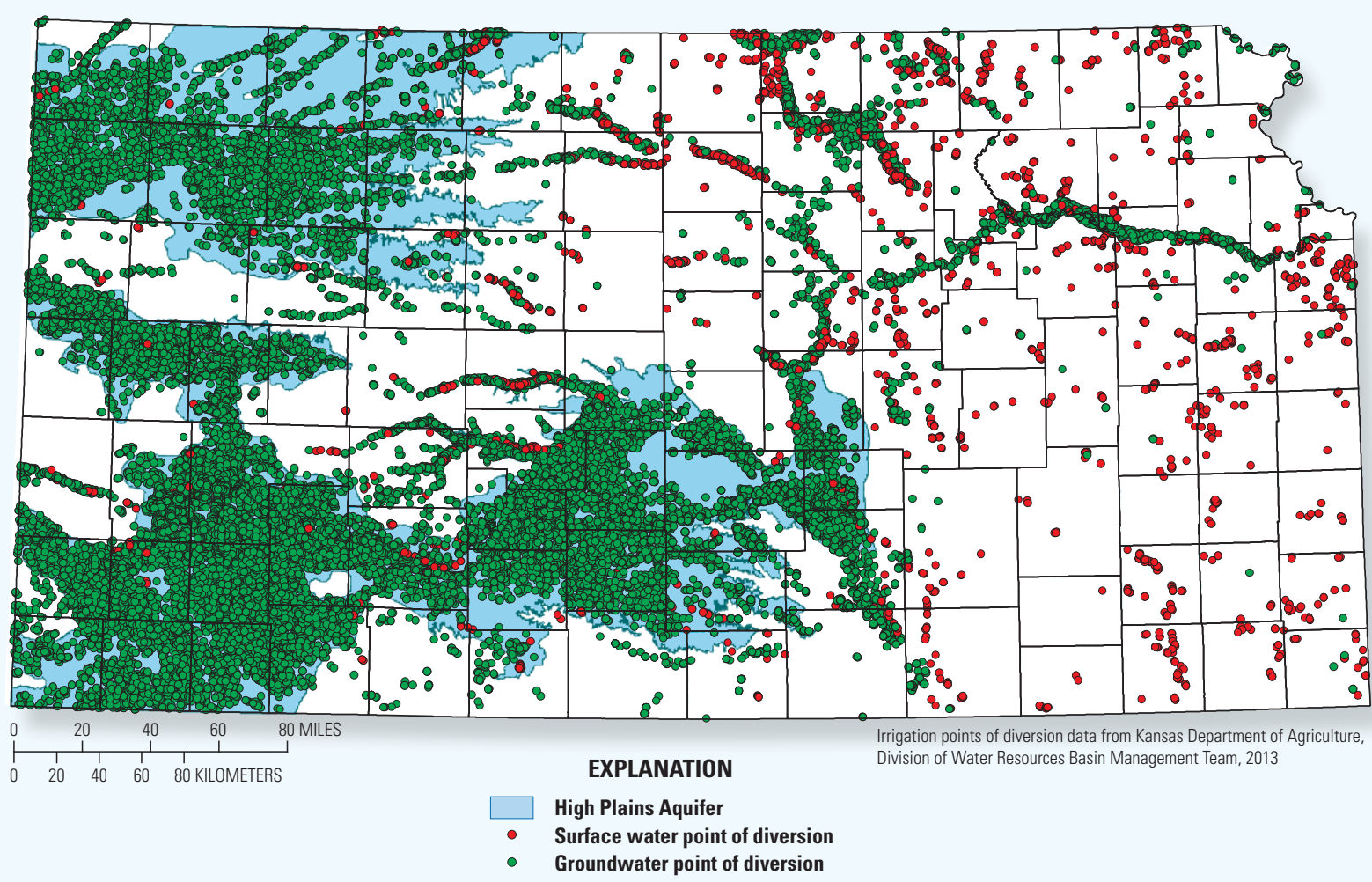

Figure 1. Location of High Plains aquifer, irrigation points of diversion, and counties in Kansas. 
Each year, reported irrigation water-use data undergo extensive review by the DWR before release through WIMAS; however, the database is dynamic, because data from previous years may be updated if better information is received. It is assumed that the data used for this report represent reasonably stable records for each year.

\section{Total Irrigation Water Use}

The reported number of acres irrigated annually in Kansas has remained fairly constant during the 21-year period from 1991 to 2011, with the lowest number of acres (2.85 million) reported for 1993 and the highest (3.27 million) reported for 2002. Water use, on the other hand, has varied greatly from year to year (fig. 2). The largest quantities of water were reported for irrigation use during the extremely dry years of 1991 (4.77 million acre-feet), 2002 (4.43 million acre-feet), and 2011 (4.27 million acre-feet). The peak water use in 1991 occurred in the fourth year of a severe drought period (National Oceanic and Atmospheric Administration, 1988-2011), but also may have been influenced by the accuracy of water-use measurements at that time. In 1991, only 14 percent of the irrigation points of diversion in Kansas were metered; by 2011, this had increased to 93 percent. The reported amount of irrigation water use is considered to be more accurate if determined using flow meters than if calculated using hours pumped and average pump rate. Overestimation of irrigation water use usually is a result of reporting pump rates that represent original rather than current pumping capacities (Kansas Water Office and Division of Water Resources, 1993).

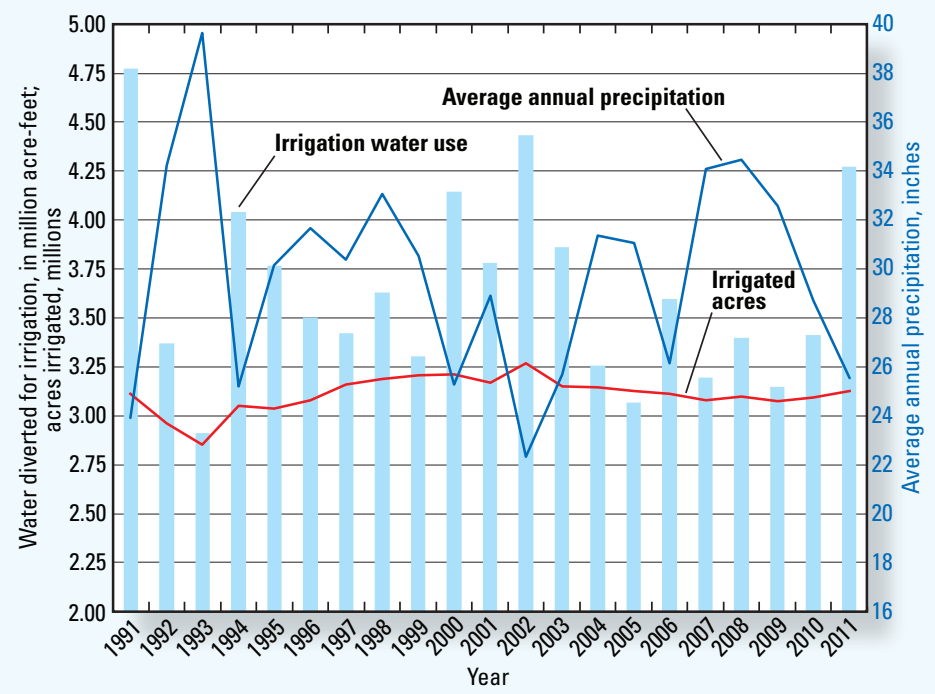

Figure 2. Reported irrigation water use, acres irrigated, and average annual precipitation, Kansas, 1991-2011 (source of precipitation data: National Oceanic and Atmospheric Administration, National Climatic Data Center, published annually).

\section{Irrigation Water Use by Crop Type}

Major crops irrigated in Kansas are alfalfa, corn, sorghum, soybeans, and wheat. Minor irrigated crops include barley, cotton, dry beans, grapes, oats, pasture, rye, and sunflowers. Self-supplied golf courses, truck farms, orchards, and nurseries also have irrigation water rights if more than 15 acre-feet per year is used.

Irrigators first indicated crop type on the 1990 irrigation water use reports, reporting acres for alfalfa, corn, sorghum, soybeans, wheat, other crops, or unspecified multiple crops. In 1992, crop reporting codes were expanded to include specific other crop types, multiple combinations of specified crop types, and double (unspecified) crop acreage. There is no assurance that multiple crop acres do not include some sequentially (double) cropped acres. The largest numbers of reported acres irrigated are for single major crop types (52 percent of reported acres in 2011), followed by specified multiple crop types (23 percent), and unspecified multiple crops ( 21 percent). Very small percentages of irrigated acres reported for 2011 were for double crops (less than 2 percent), minor crops (less than 2 percent), and noncrop uses such as golf courses ( 0.5 percent).

Trends in estimated irrigated acres by crop type from 1992 to 2011 are shown in figure 3. Estimated acres of major and other crop types irrigated each year were determined by adding the reported acres of single crop types to prorated multiple and double crop acres. Acres reported as multiple specified crops were divided equally among the crops indicated. Unspecified acres in each county were assigned to major and other crop types in the proportion that these crops were specified in the same county. Proration of multiple and unspecified crop acres was not possible for 1991 because of the limited information on crop type provided that year.

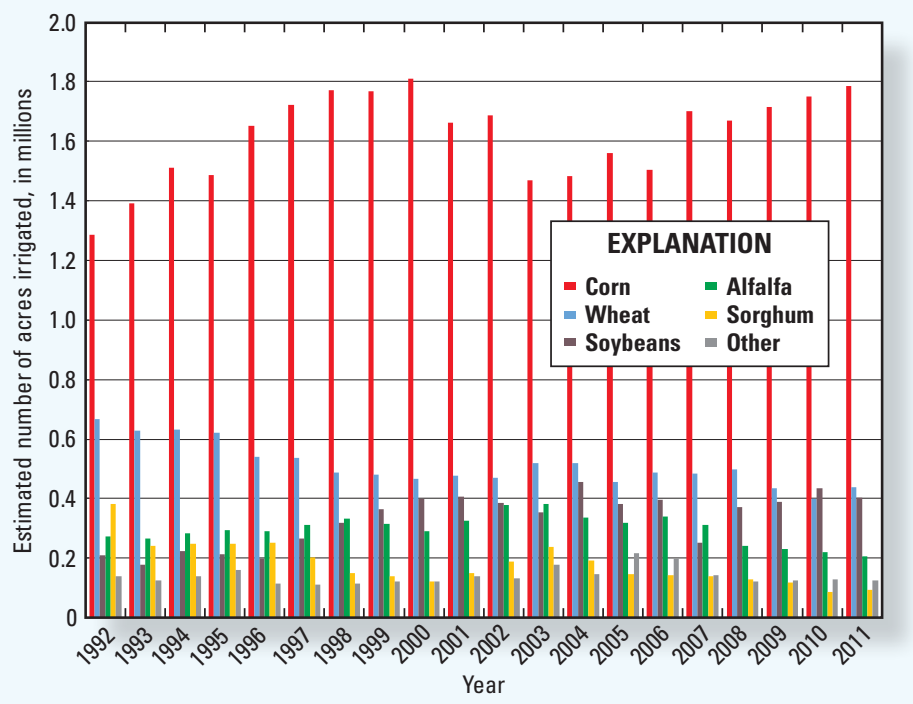

Figure 3. Estimated acres irrigated by major crop type in Kansas, 1992-2011.

The most common irrigated crop in Kansas is corn. Estimated irrigated corn acreage has increased cyclically over the 20-year period, from approximately 1.29 million acres in 1992 to 1.81 million acres in 2000 and 1.78 million acres in 2011 . Irrigated corn represented 43 percent of the total irrigated acreage in 1992, 56 percent in 2000, and 58 percent in 2010 and 2011.

Estimated acres of other major crops fluctuated over the 20 -year period. Overall declines were noted in acres of irrigated wheat and sorghum, whereas acres of irrigated soybeans increased. 


\section{Irrigation Water Use by System Type}

Information on system type was first collected on the 1991 irrigation water-use reports, using five reporting options: flood, subsurface drip, center pivot, other sprinkler, or other. For 1992-95, acres irrigated with center pivot Low Energy Precision Application (LEPA) were identified. Beginning in 1996, acres irrigated using center pivot with drop nozzles were identified on the water-use reports because this system type had become more common than LEPA. Beginning in 2002, acres irrigated with combination system type (pivot with flood; drip and other) were identified.

Trends in acres irrigated by system type from 1991 to 2011 are shown in figure 4. During this time, total acres irrigated using flood systems steadily decreased from 1.42 million acres to 134,000 acres, or from 46 percent to 4 percent of the total acres irrigated. Center pivot systems became the predominant method of irrigating during this time, with the greatest increase in irrigated acres reported for center pivot systems with drop nozzles. By 2011, about 2.32 million acres were irrigated using center pivots with drop nozzles, or 76 percent of the total acres reported. This shift was encouraged by State and Federal investment in equipment cost sharing, intended to reduce consumptive use of groundwater from the High Plains aquifer (Perry, 2006; Pfeiffer and Lin, 2010).

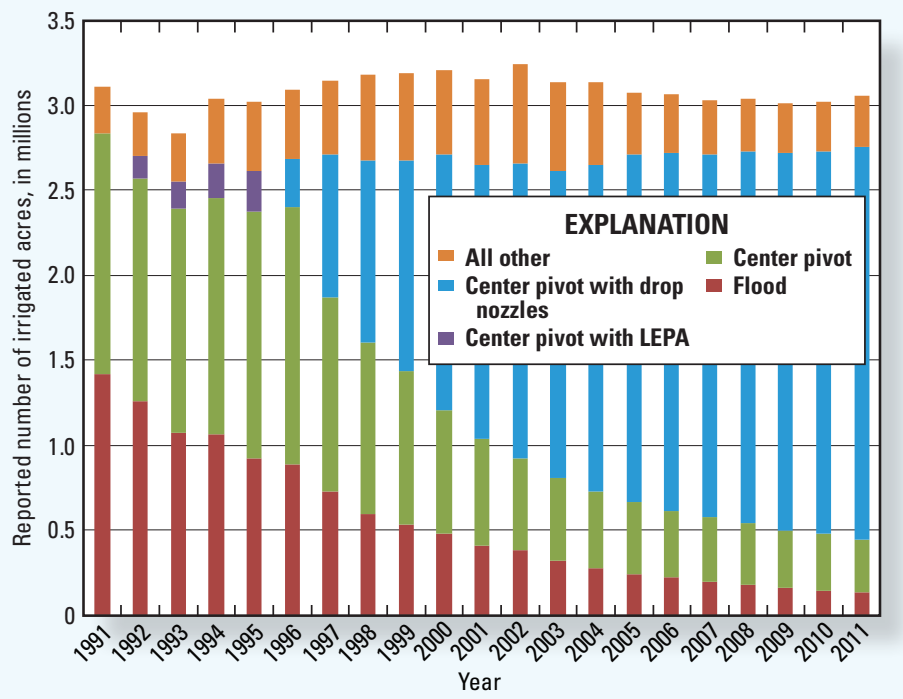

Figure 4. Reported acres irrigated by system type in Kansas, 1991-2011. [LEPA, Low Energy Precision Application]

\section{Irrigation Application Rates by Crop Type and System Type}

Average irrigation application rates were computed as the total amount of water pumped divided by the corresponding number of acres irrigated. Approximations of consumptive use, conveyance losses, and irrigation system efficiency were not part of this equation. On a local basis, irrigation application rates are affected by precipitation, soil permeability, temperature, wind, crop type, length of irrigation season, and irrigation system type (Perry, 2006). Annual application rates calculated using total reported water use and acres irrigated also are affected by metering and reporting accuracy, and by the fact that a given number of acres reported as irrigated may be cropped multiple times in a year. It is not possible to determine the actual numbers of acres of each crop irrigated when multiple crops are indicated on the reports, or whether the different crops were grown on the entire acreage sequentially or on separate parts of the total acreage. Therefore, overall irrigation application rates may appear higher if many acres were cropped multiple times in a year, or if pre-irrigation occurred in addition to irrigation of the specified crop acreage.

The State average irrigation application rate in Kansas for the years 1991 through 2011 was 1.13 acre-feet per acre (acre$\mathrm{ft} / \mathrm{acre}$ ) and ranged from $0.97 \mathrm{acre}-\mathrm{ft} / \mathrm{acre}$ in 2005 to 1.49 acre$\mathrm{ft} /$ acre in 1991. State average irrigation application rates of 1 acre-foot per acre or less occurred in the flood year of 1993, as well as in 1999, 2005, and 2009. The largest average irrigation application rates occurred in the dry years 1991, 1994, 2002, and 2011 (National Oceanic and Atmospheric Administration, 1988-2011).

Irrigation application rates were calculated using water use and irrigated acres reported by major crop type. Statewide average annual application rates, in acre-feet/acre, are shown in figure 5 for single-crop acres of alfalfa, corn, sorghum, soybeans, and wheat, plus all other and multiple crops. Alfalfa received the largest application of irrigation, ranging from 1.24 to $1.78 \mathrm{acre}-\mathrm{ft} / \mathrm{acre}$, and averaging $1.45 \mathrm{acre}-\mathrm{ft} /$ acre from 1991 to 2011. Corn irrigation application rates ranged from 1.06 to $1.57 \mathrm{acre}-\mathrm{ft} / \mathrm{acre}$, and averaged $1.26 \mathrm{acre}-\mathrm{ft} / \mathrm{acre}$ over the 21-year period. Average statewide irrigation application rates for 1991-2011 were 0.96 for soybeans, 0.81 for sorghum, 0.70 for wheat, and 1.06 acre-ft/acre for all other and multiple crops. The average annual application rate for all crops was largest in 1991, followed by 2011 and 2002.

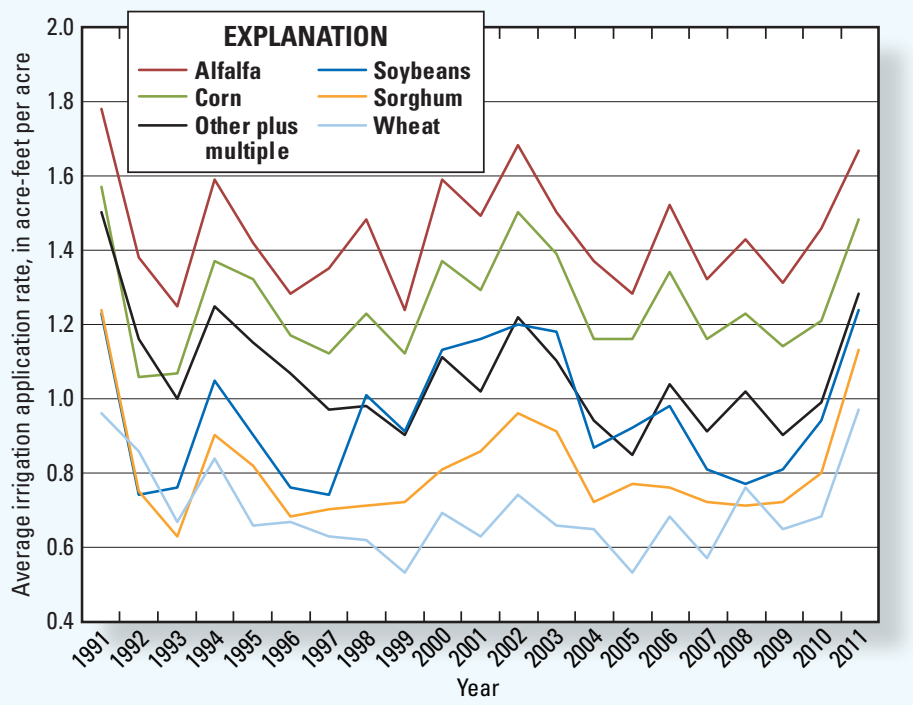

Figure 5. Average irrigation application rate by crop type in Kansas, 1991-2011.

Irrigation application rates also were calculated using reported information on water use and irrigated acres by system type. Average irrigation application rates for 1991-2011 for flood, center pivot, center pivot with LEPA, center pivot with drop nozzles, and all other types of irrigation systems combined are shown in figure 6. From 1991 to 1997, the largest irrigation 


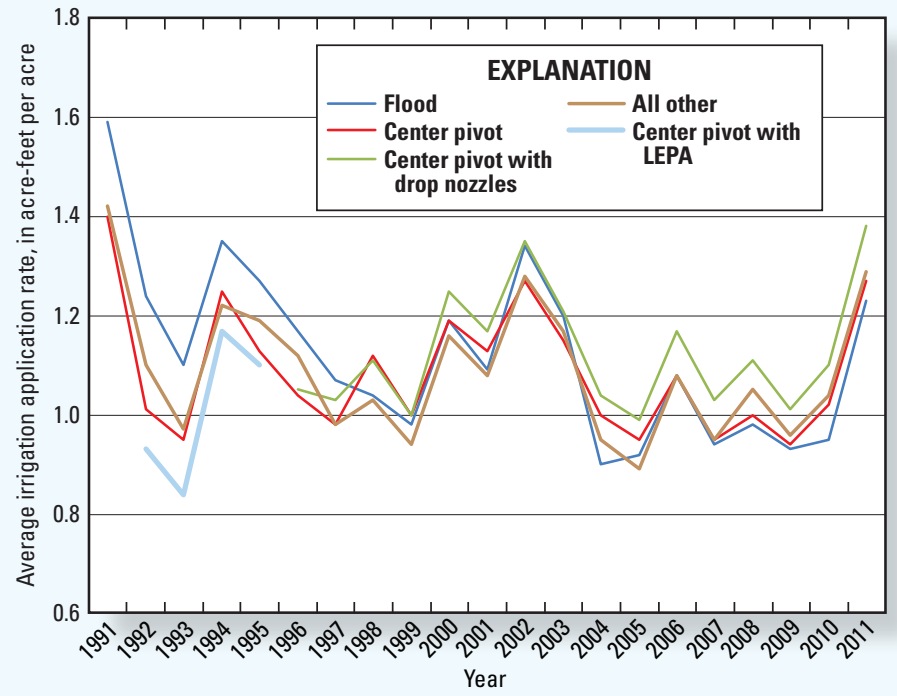

Figure 6. Average irrigation application rate by system type in Kansas, 1991-2011. [LEPA, Low Energy Precision Application]

application rates occurred on acres irrigated by flood systems. After 1998, the largest irrigation application rates generally occurred on acres irrigated using center pivots with drop nozzles. This increased application rate for center pivots with drop nozzles may indicate that more land is being irrigated for multiple seasons and crops or that more water-intensive crops are being grown.

\section{Acknowledgments}

This study was made possible, in part, by support from the Kansas Department of Agriculture, Division of Water Resources, and the Kansas State Water Plan Fund.

\section{References Cited}

Kansas Department of Agriculture and Kansas Geological Survey, 2013, Water Information Management and Analysis System (WIMAS): Kansas Department of Agriculture, Division of Water Resources database, accessed April-May 2013, at http://hercules.kgs.ku.edu/geohydro/wimas/index.cfm.

Kansas Geological Survey, 2013, Groundwater levels decline in western and central Kansas: [News release issued February 4, 2013], accessed August 2013, at http://www.kgs. ku.edu/General/News/2013/2013groundwaterlevels.html.

Kansas Water Office and Division of Water Resources, 1993, 1991 Kansas Irrigation Water Use: Topeka, Kans., 115 p.

McGuire, V.L., 2009, Water-level changes in the High Plains aquifer, predevelopment to 2007, 2005-06, and 2006-07: U.S. Geological Survey Scientific Investigations Report 2009-5019, 9 p.

National Oceanic and Atmospheric Administration, 1988-2011, Climatological data, annual summary, Kansas: Asheville, North Carolina, National Climatic Data Center, v. 102-125 [published annually].

Perry, C.A., 2006, Effects of irrigation practices on water use in the Groundwater Management Districts within the Kansas High Plains, 1991-2003: U.S. Geological Survey Scientific Investigations Report 2006-5069, 93 p.

Pfeiffer, Lisa, and Lin, Cynthia C.-Y., 2010, The effect of irrigation technology on groundwater use: Choices Magazine, v. 25 , no. 3,6 p.

For additional information concerning this publication, contact: Director, USGS Kansas Water Science Center 4821 Quail Crest Place

Lawrence, KS 66049

(785) 842-9909

Or visit the Kansas Water Science Center Web site at: http://ks.water.usgs.gov
Center pivot irrigation system with drop nozzles in western Kansas, photograph taken by Lori Marintzer, U.S. Geological Survey.

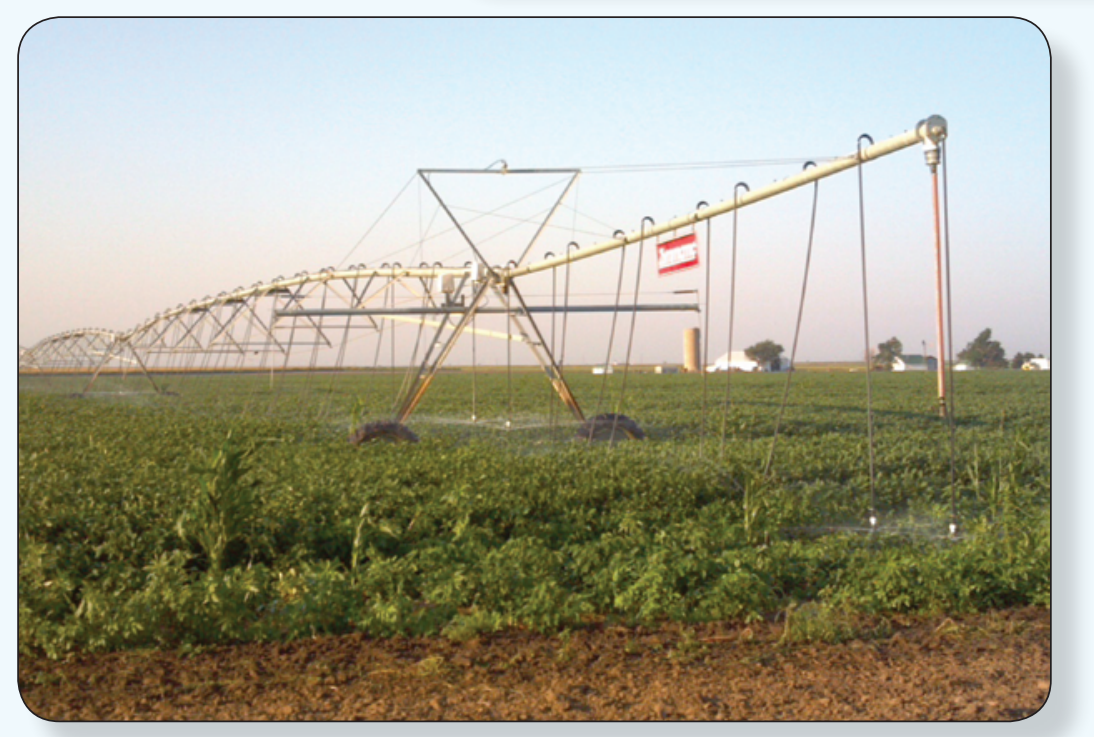

